\title{
Electrical and Electrorheological Properties of Alumina/Natural Rubber (STR XL) Composites
}

Nuchnapa Tangboriboon ${ }^{1}$, Nuttapot Uttanawanit ${ }^{1}$, Mean Longtong ${ }^{1}$, Piraya Wongpinthong ${ }^{1}$, Anuvat Sirivat $^{2, *}$ and Ruksapong Kunanuruksapong ${ }^{2}$

1 Department of Materials Engineering, Faculty of Engineering, Kasetsart University, Bangkok 10900, Thailand; E-Mails: fengnnpt@ku.ac.th (N.T.); nuttapoth@hotmail.com (N.U.); uv3w@hotmail.com (M.L.); narinninja@hotmail.com (P.W.)

2 The Petroleum and Petrochemical College, Chulalongkorn University, Bangkok 10330, Thailand; E-Mail: amd64best@hotmail.com

* Author to whom correspondence should be addressed; E-Mail: anuvat.s@chula.ac.th; Tel.: +66-2-218-4131; Fax: +66-2-611-7221.

Received: 18 December 2009; in revised form: 19 January 2010 / Accepted: 21 January 2010 / Published: 22 January 2010

\begin{abstract}
The electrorheological properties (ER) of natural rubber (XL)/alumina $\left(\mathrm{Al}_{2} \mathrm{O}_{3}\right)$ composites were investigated in oscillatory shear mode under DC electrical field strengths between 0 to $2 \mathrm{kV} / \mathrm{mm}$. SEM micrographs indicate a mean particle size of $9.873 \pm 0.034 \mu \mathrm{m}$ and particles that are moderately dispersed in the matrix. The XRD patterns indicate $\mathrm{Al}_{2} \mathrm{O}_{3}$ is of the $\beta$-phase polytype which possesses high ionic conductivity. The storage modulus $\left(\mathrm{G}^{\prime}\right)$ of the composites, or the rigidity, increases by nearly two orders of magnitude, with variations in particle volume fraction and electrical field strength. The increase in the storage modulus is caused the ionic polarization of the alumina particles and the induced dipole moments set up in the natural rubber matrix.
\end{abstract}

Keywords: natural rubber; dielectric elastomer; alumina

\section{Introduction}

Combining a dielectric ceramic and a polymer host to form a flexible dielectric composite is interesting in view of the greater flexibility in tailoring these materials towards particular mechanical, electrical, and thermal properties, and/or a coupling between these properties [1,2]. Carpi et al. 
reported the actuation performances of elastomeric dielectric materials used as electromechanical transducers [3]. López-Manchado et al. studied the influence of inorganic nanoparticles on elastomer crosslinking mechanisms. The role of inorganic particles has been evaluated using the tube model theory [4]. Molecular network parameters derived from this model point out a different filler/elastomer reinforcement mechanism as a function of filler. Even a small amount of inorganic nanoparticles is sufficient to interact with the entire matrix. Furthermore, these inorganic nanoparticles mainly exhibit physical adsorptions with the elastomer due to its inorganic nature [4].

The backbone of natural rubber (NR), polyisoprene, is derived from the polyacetylene backbone through the saturation of every other double bond. Polyisoprene is a potential candidate for materials used in various devices: solar cells, LEDs, and FETs. Natural rubbers combine high tensile strength, flexibility, and tear strength with outstanding resistance to fatigue [5,6]. External stimuli, including electrical fields, temperature, and stress may cause the methyl substitute attached to the unsaturated sites in polyisoprene to induce the electron-releasing tendency of the backbone. The pristine polyisoprene chains generally have a random coil conformation in various organic solvents over a range of concentrations. However, natural rubber (NR), unlike many other polymers, is highly susceptible to many forms of degradation: heat, humidity, light, ozone, and radiation, due to the presence of double bonds in the main chain.

Alumina is a linear dielectric material with ionic polarization with potential uses as electrolytic capacitors, optical and photoluminescent materials [7]. The most common form of crystalline alumina is corundum, which has a rhombohedral Bravais lattice with a space group R-3c (Number 167 in the International Tables). Alumina also exists in other phases, namely $\eta, \gamma, \theta$, and $\delta$ theta alumina. All phases have a structure with a spinel-like Al-O network similar to that found in the $\beta$-alumina polytypes. Sutorik et al. reported that $\beta$ - and $\beta$ "-alumina are high temperature solid electrolytes that exhibit high ionic conductivity. These materials have been used in energy storage, alkali-metal thermal-to-electric conversion (AMTEC) cells, and gas sensors [8]. Many of the challenges in working with $\beta$ - and $\beta$ "-alumina result from the desire to optimize the formation of $\beta$ "-alumina (which has the higher ionic conductivity) over that of $\beta$-alumina. The structures of $\beta$ - and $\beta$ "-alumina are closely related polytypes; both have the same general stacking pattern of Al-O spinel-like blocks separated by $\mathrm{Na}-\mathrm{O}$ planes [7,9]. $\beta$-alumina has the interlayer Na-O lying on a crystallographic mirror plane and two Al-O blocks per unit cell. $\beta$ "-alumina, rather, has a three-fold screw axis perpendicular to the planes and consequently possesses three Al-O blocks in its unit cell. In general, the properties of alumina $\left(\mathrm{Al}_{2} \mathrm{O}_{3}\right)$ are a low thermal-expansion, a good thermal-shock fracture resistance, a low density, high creep resistance, good chemical and thermal stability, a high melting point $\left(1,828 \pm 10{ }^{\circ} \mathrm{C}\right)$, and excellent toughness and strength. Vinod et al. and Jakubowickz reported that alumina can also reduce heat, humidity, light, ozone and gamma radiation, flame resistance, and the crack growth in natural rubber [10-11]. Alumina $\left(\mathrm{Al}_{2} \mathrm{O}_{3}\right)$ is a potential candidate as the dispersed phase in the natural rubber matrix [12-13]. Factors such as size distribution, shape, volume fraction, permittivity, and conductivity of the particles and the host solvent, have been well known to affect the electrical and rheological properties of the polyisoprene based blends or composites [14-21]. Composite potential applications are the dissipation of an electrostatic charge; the electrostriction, the ion insertion, and molecular conformational changes towards the development of friction/anti-friction materials, and the responses from external stimuli such as changes in $\mathrm{pH}$, temperature, time, light, ionic concentration or 
electrical field [14-21]. Recently, several designs based on electrorheological (ER) materials have led to the developments of a broad range of devices: brakes, dampers, clutches, adaptive structures, actuators, artificial muscles, prostheses, toys, robotics, and biomimetic devices [5,14,22-25].

The aim of this work was to study the electrical and electrorheological properties of composites based on alumina particles (the dispersed phase) embedded in a dried natural rubber type XL (matrix or the continuous phase). In addition, detailed characterizations by SEM, FTIR, and XRF of composites, the matrix, and the dispersed phase shall be reported.

Figure 1. FTIR spectra: natural rubber (XL), alumina $\left(\mathrm{Al}_{2} \mathrm{O}_{3}\right)$, and $\mathrm{XL} / \mathrm{Al}_{2} \mathrm{O}_{3}$ composites.

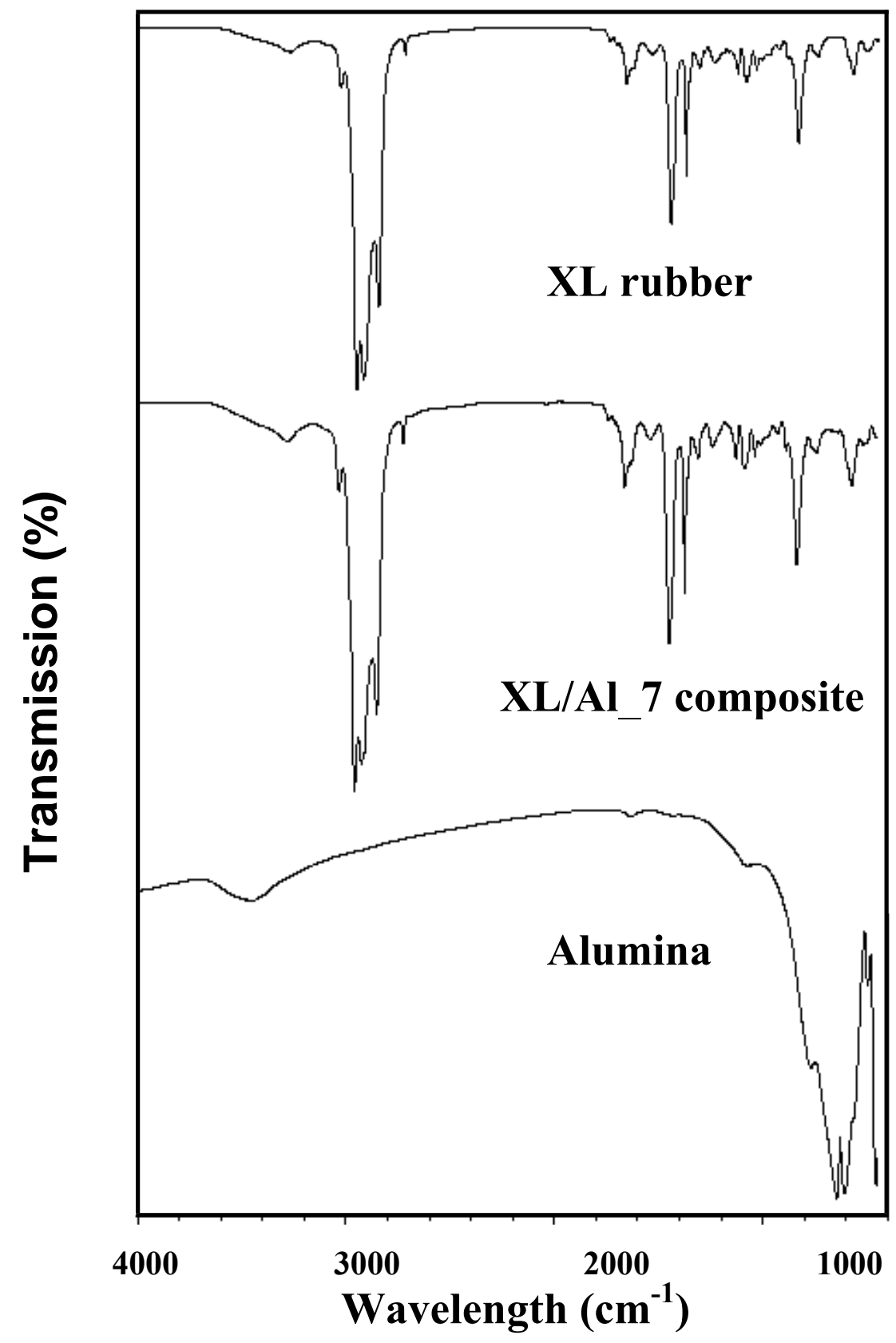




\section{Results and Discussion}

\subsection{Characterization of Natural Rubber (XL)/Alumina $\left(\mathrm{Al}_{2} \mathrm{O}_{3}\right)$}

The mean diameter of alumina particles is $9.873 \pm 0.034 \mu \mathrm{m}$, as determined by the particle size analyzer, and consistent with that found by SEM. The chemical composition of alumina powder, as measured by the X-ray fluorescence is $99.74 \%$ (that is, $0.26 \%$ impurity content). The FTIR spectra of alumina $\left(\mathrm{Al}_{2} \mathrm{O}_{3}\right)$, natural rubber $(\mathrm{XL})$ and the $\mathrm{XL} / \mathrm{Al}_{2} \mathrm{O}_{3}$ composites are shown in Figure 1; the peaks are identified and tabulated in Table 1.

Table 1. FTIR spectra of natural rubber (XL), alumina (Al), and $\mathrm{XL} / \mathrm{Al}_{2} \mathrm{O}_{3}$ composites.

\begin{tabular}{|c|c|}
\hline Wave Number $\left(\mathrm{cm}^{-1}\right)$ & Functional Groups \\
\hline $\begin{array}{l}3281,3467(\mathrm{CAS} 7732-18-5) \\
(\mathrm{CAS} 78-79-5)\end{array}$ & $\mathrm{OH}$ stretching of $\mathrm{Al}_{2} \mathrm{O}_{3}$ added natural rubber $(\mathrm{XL})$ \\
\hline 2961, 3036 (CAS78-79-5) & $\begin{array}{l}-\mathrm{CH} \text { and }=\mathrm{CH} \text { stretching vibration of poly-acetylene } \\
\text { backbone of isoprene }\end{array}$ \\
\hline $2855,2928(\mathrm{CAS} 78-79-5)$ & $-\mathrm{CH}_{2}$ stretching vibration of $\mathrm{C}-\mathrm{CH}_{2} \mathrm{CH}_{3}$ \\
\hline $1663,1710(\mathrm{CAS} 78-79-4)$ & $>\mathrm{C}=\mathrm{C}$ stretching for carbon-carbon double bond \\
\hline $\begin{array}{l}1448(\text { CAS78-79-5); } \\
(\text { CAS110-54-3); } \\
(\text { CAS73513-42-5) }\end{array}$ & - $\mathrm{CH}_{3}$ asymmetric deformation \\
\hline $1376(\mathrm{CAS} 78-79-5)$ & - $\mathrm{CH}_{3}$ deformation of $\mathrm{O}-\mathrm{CH}_{2} \mathrm{CH}_{3}$ \\
\hline $1242,1288(\mathrm{CAS} 110-54-3)$ & Asymmetric C-O-C stretching vibration \\
\hline 1128 & R-CO-R symmetric stretching \\
\hline $\begin{array}{l}740,762,1038,1084 \\
(\mathrm{CAS} 110-54-3)\end{array}$ & Skeletal vibration of hexane and $=\mathrm{CH}$ bending \\
\hline 572,639 & Al-O-C stretching \\
\hline
\end{tabular}

The characteristic peaks of $\mathrm{XL} / \mathrm{Al}_{2} \mathrm{O}_{3}$ are at 3,600-3,200 $\mathrm{cm}^{-1} v(\mathrm{O}-\mathrm{H}), 3,000-2,900 \mathrm{~cm}^{-1} v(\mathrm{C}-\mathrm{H})$ and $(=\mathrm{CH}), 2,900-2,800 \mathrm{~cm}^{-1} v\left(\mathrm{CH}_{2}\right), 1,800-1,600 \mathrm{~cm}^{-1} v(\mathrm{C}=\mathrm{C}), 1,500-1,300 \mathrm{~cm}^{-1}\left(\mathrm{CH}_{3}\right.$ asymmetric deformation), 1,300-1,100 $\mathrm{cm}^{-1} v(\mathrm{C}-\mathrm{O}-\mathrm{C}), 1,100-740 \mathrm{~cm}^{-1}$ (=CH bending), and $640-580 \mathrm{~cm}^{-1} v(\mathrm{Al}-\mathrm{O})$. Our FTIR result is consistent with those reported by Ismail et al. [24] and Kansal et al. [28]. The XRD patterns of $\mathrm{XL}, \mathrm{Al}_{2} \mathrm{O}_{3}$, and $\mathrm{XL} / \mathrm{Al}_{2} \mathrm{O}_{3}$, are shown in Figure 2.

The XRD patterns of alumina powder and $\mathrm{XL} / \mathrm{Al}_{2} \mathrm{O}_{3}$ resemble those recorded at the International Center for Diffraction Data (JCPDS numbers 00-042-1458 with the corundum phase form and 01-0700384 with the hexagonal phase form). This observation indicates a partial phase transformation from the corundum phase (rhombohedral) to $\beta$ - and $\beta "$-alumina forms (hexagonal). The structures of $\beta$ - and $\beta$ "-alumina are the closely related polytypes; both have the same general stacking pattern of Al-O spinel-like blocks separated by $\mathrm{Na}-\mathrm{O}$ planes [7]. The $\beta$ - and $\beta$ "-alumina forms exhibit high ionic conductivity; impurity ions $\left(\mathrm{K}^{+}, \mathrm{Ca}^{2+}\right.$, and $\left.\mathrm{Na}^{+}\right)$as traced by XRF can migrate through a surplus of cationic sites in the crystal lattice. The microstructures of pure natural rubber (XL), XL/Al_6, and XL/Al_7, and alumina particles are shown in SEM micrographs of Figure 3. The particle size distribution and the shapes of the particles have a significant effect on the particle packing and pore structure, on the deformation behavior, and on the electrical and rheological properties. The calculated 
and experimental density values of $\mathrm{XL} / \mathrm{Al}_{2} \mathrm{O}_{3}$ composites are: 0.9200 and $0.9428 \mathrm{~g} / \mathrm{cm}^{3}$ (XL/Al_0); 0.9216 and $0.9449 \mathrm{~g} / \mathrm{cm}^{3}$ (XL/Al_1); 0.9274 and $0.9527 \mathrm{~g} / \mathrm{cm}^{3}$ (XL/Al_2); 0.9333 and $0.9607 \mathrm{~g} / \mathrm{cm}^{3}$ (XL/Al_3); 0.9383 and $0.9674 \mathrm{~g} / \mathrm{cm}^{3}$ (XL/Al_4); 0.9424 and $0.9730 \mathrm{~g} / \mathrm{cm}^{3}$ (XL/Al_5); 0.9460 and $0.9780 \mathrm{~g} / \mathrm{cm}^{3}$ (XL/Al_6); and 0.9489 and $0.9818 \mathrm{~g} / \mathrm{cm}^{3}$ (XL/Al_7).

Figure 2. $\mathrm{XRD}$ peak patterns of natural rubber $(\mathrm{XL})$, alumina $\left(\mathrm{Al}_{2} \mathrm{O}_{3}\right)$, and $\mathrm{XL} / \mathrm{Al}_{2} \mathrm{O}_{3}$ composites.

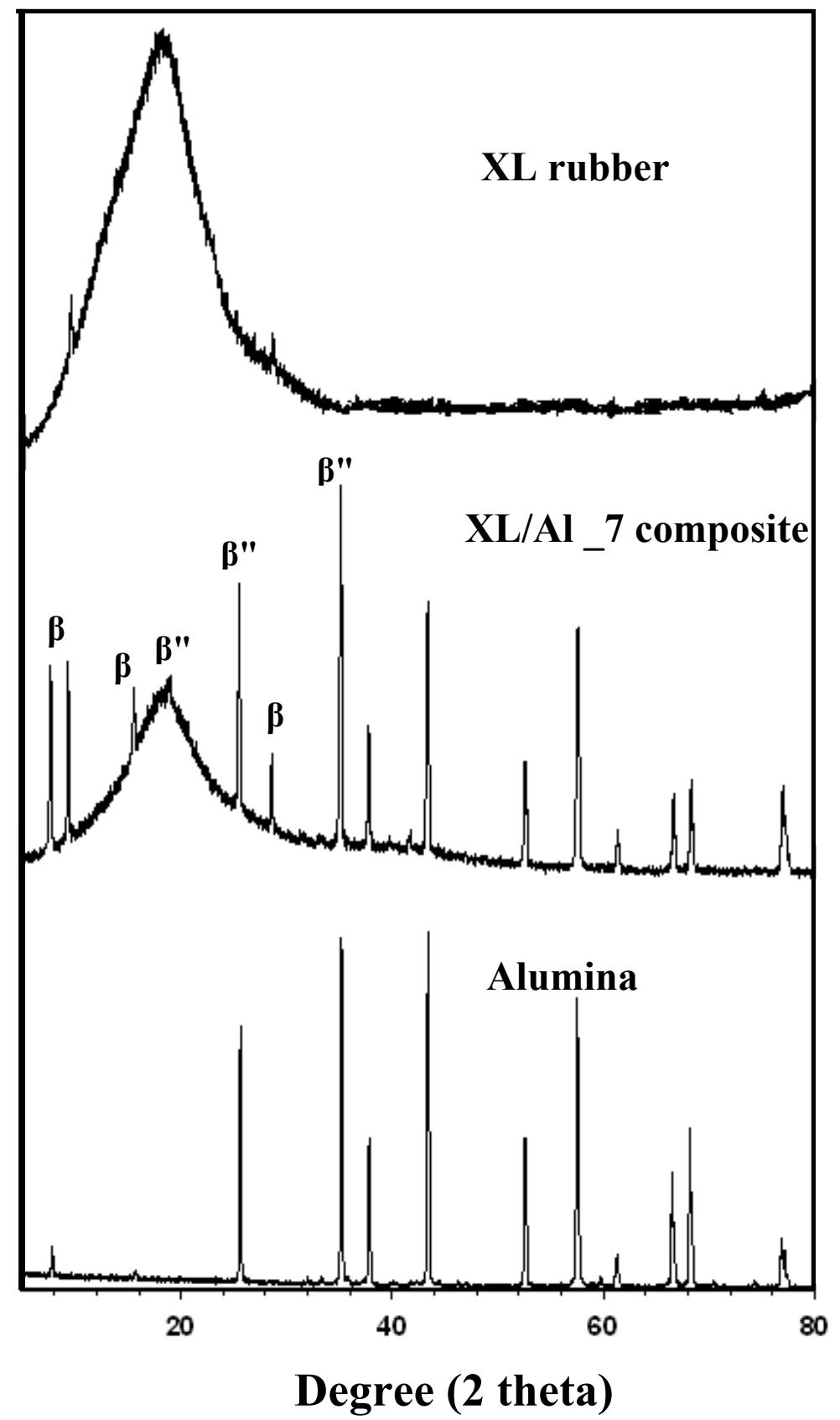


Figure 3. SEM micrographs of samples: (a) Natural rubber (XL), (b) Alumina powder $\left(\mathrm{Al}_{2} \mathrm{O}_{3}\right),(\mathrm{c}) \mathrm{XL} / \mathrm{Al} \_6$, and (d) XL/Al_7.

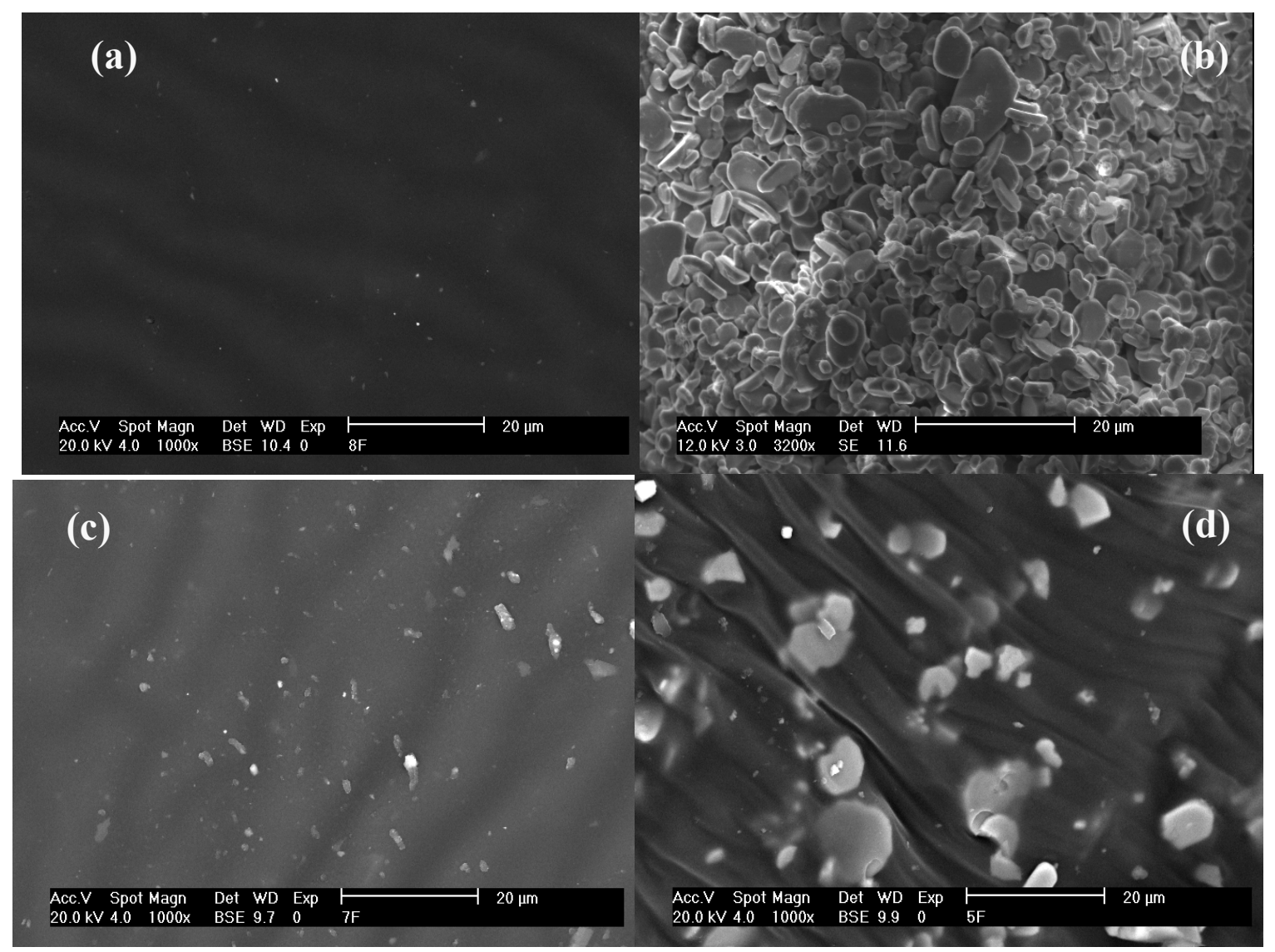

\subsection{Electrical Properties of Natural Rubber (XL)/Alumina $\left(\mathrm{Al}_{2} \mathrm{O}_{3}\right)$}

The electrical properties of the non-conducting natural rubber (XL), the insulating material $\left(\mathrm{Al}_{2} \mathrm{O}_{3}\right)$, and $\mathrm{XL} / \mathrm{Al}_{2} \mathrm{O}_{3}$ composites were measured by the impedance analyzer; the data are tabulated in Table 2 and shown in Figure 4. With increasing particulate volume fraction, the electrical conductivity and the dielectric constant increase gradually. The dielectric constant values are 1.542, 11.811, and 2.123 for $\mathrm{XL}, \mathrm{Al}_{2} \mathrm{O}_{3}$, and XL/Al_7, respectively. The electrical conductivity values of $\mathrm{XL}, \mathrm{Al}_{2} \mathrm{O}_{3}$, and XL/Al_7 are $6.517 \times 10^{-9}, 1.502 \times 10^{-7}$, and $2.683 \times 10^{-8}(\Omega . \mathrm{m})^{-1}$, respectively. The electrical conductivity of XL/Al_7 composite is approximately two orders of magnitude higher than that of the natural rubber $\mathrm{XL}$. The polyisoprene can be swollen by the hexane, and the alumina is intercalated in the natural rubber XL matrix. The alumina has a partial phase transformation from rhombohedral to the hexagonal $\beta$ - and $\beta "$ - phase formations as shown by the XRD pattern. The $\beta$ - and $\beta "$ - alumina phases have high ionic conductivity [7]. The effect of a methyl group on the double bond of natural rubber XL is to stabilize the cationic structure. The ionic polarization mechanism of $\mathrm{XL} / \mathrm{Al}_{2} \mathrm{O}_{3}$ acts as $\mathrm{Al}-\mathrm{O}$ spinel-like blocks in Na-O planes under an applied AC electrical field. 
Table 2. Electrical properties of $\mathrm{XL} / \mathrm{Al}_{2} \mathrm{O}_{3}$ measured at room temperature and at $500 \mathrm{~Hz}$.

\begin{tabular}{|c|c|c|c|c|c|c|}
\hline Code & $\begin{array}{l}\text { Mass of } \\
\text { XL (g) }\end{array}$ & $\begin{array}{c}\text { Mass of } \\
\mathrm{Al}_{2} \mathrm{O}_{3} \text { (g) }\end{array}$ & $\begin{array}{c}\text { Volume } \\
\text { fraction of } \\
\mathrm{Al}_{2} \mathrm{O}_{3}(\Phi) \\
\end{array}$ & $\begin{array}{l}\text { Dielectric } \\
\text { constant } \varepsilon^{\prime} \\
\text { at } 500 \mathrm{~Hz} \\
\end{array}$ & $\begin{array}{c}\text { Dielectric } \\
\text { loss factor } \\
\varepsilon^{\prime \prime} \text { at } 500 \mathrm{~Hz} \\
\end{array}$ & $\begin{array}{c}\text { Conductivity } \\
(\Omega . m)^{-1}, \sigma \text { at } \\
500 \mathrm{~Hz}\end{array}$ \\
\hline $\mathrm{Al}_{2} \mathrm{O}_{3}$ & 0.0000 & 1.0000 & 1.00000 & 11.811 & $7.66 \mathrm{E}-03$ & $1.502 \mathrm{E}-07$ \\
\hline XL/Al_0 & 3.0000 & 0.0000 & 0.00000 & 1.542 & $6.84 \mathrm{E}-04$ & $6.517 \mathrm{E}-09$ \\
\hline XL/Al_1 & 3.0000 & 0.0069 & 0.00054 & 1.343 & $2.15 \mathrm{E}-04$ & 7.685E-09 \\
\hline XL/Al_2 & 3.0000 & 0.0316 & 0.00248 & 1.357 & $1.44 \mathrm{E}-03$ & $8.688 \mathrm{E}-09$ \\
\hline XL/Al_3 & 3.0000 & 0.0572 & 0.00448 & 1.436 & $1.36 \mathrm{E}-03$ & $1.235 \mathrm{E}-08$ \\
\hline XL/Al_4 & 3.0000 & 0.0784 & 0.00613 & 1.518 & $1.52 \mathrm{E}-03$ & $1.471 \mathrm{E}-08$ \\
\hline XL/Al_5 & 3.0000 & 0.0961 & 0.00750 & 1.550 & $1.58 \mathrm{E}-03$ & $1.594 \mathrm{E}-08$ \\
\hline XL/Al_6 & 3.0000 & 0.1120 & 0.00873 & 1.575 & $1.96 \mathrm{E}-04$ & $1.937 \mathrm{E}-08$ \\
\hline XL/Al_7 & 3.0000 & 0.1243 & 0.00968 & 2.123 & $1.65 \mathrm{E}-04$ & $2.683 \mathrm{E}-08$ \\
\hline
\end{tabular}

Measured at $27^{\circ} \mathrm{C}$; Density XL is $0.92 \mathrm{~g} / \mathrm{cm}^{3}$; Density $\mathrm{Al}_{2} \mathrm{O}_{3}$ powder is $3.90 \mathrm{~g} / \mathrm{cm}^{3}$;

$\mathrm{XL}$ rubber has extra light color.

Figure 4. Electrical properties of $\mathrm{Al}_{2} \mathrm{O}_{3}$ and $\mathrm{XL} / \mathrm{Al}_{2} \mathrm{O}_{3}$ composites vs. volume fraction.

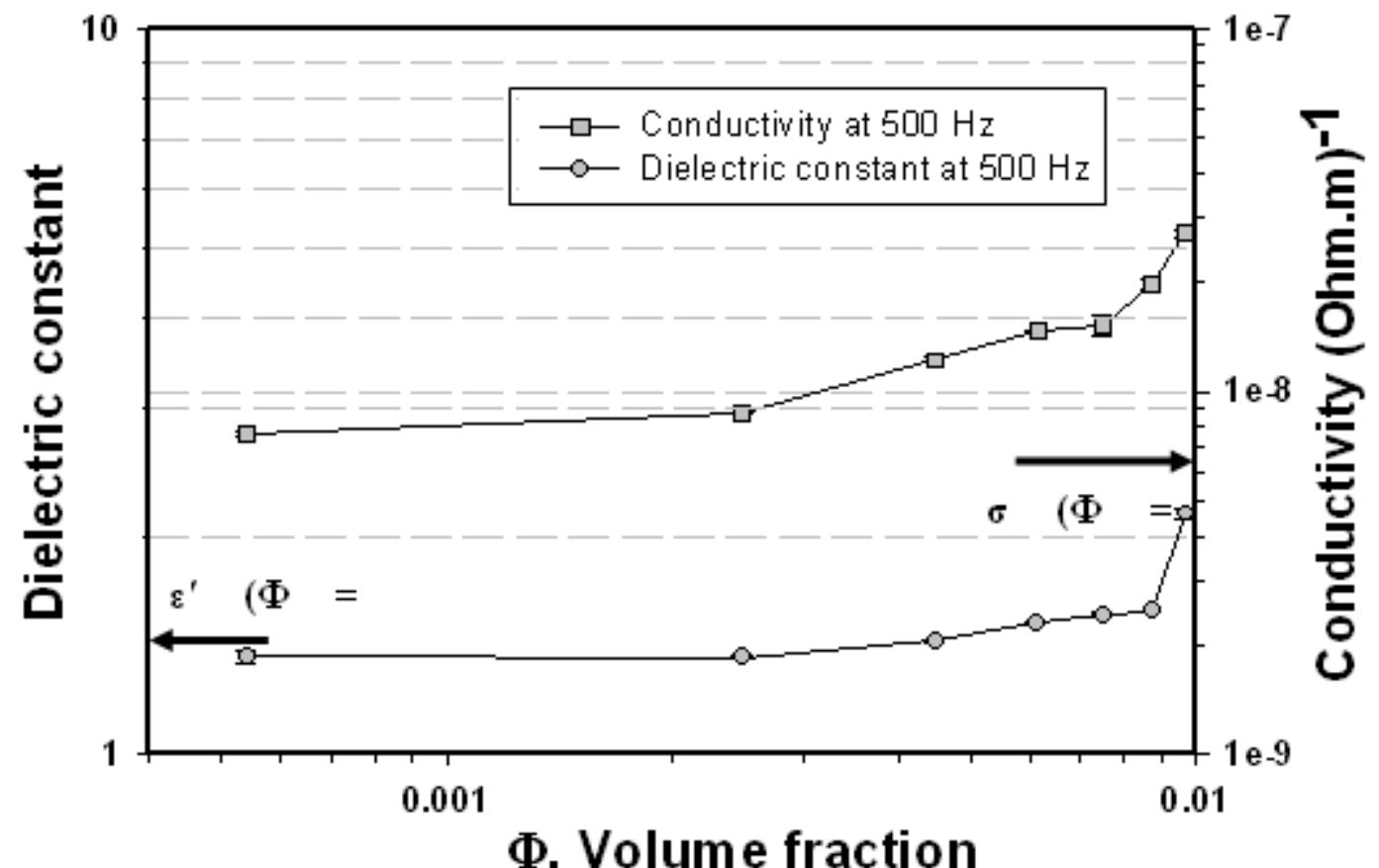

\subsection{Electrorheological Properties: Time Dependence, Effects of Particle Concentration and Electric} Field Strength

Figure 5 shows the temporal characteristics of pure natural rubber XL (XL/Al_0) and XL/Al_7 from time sweep tests in which an electrical field was alternately turned on and off. The temporal characteristics of the samples were recorded in the linear viscoelastic regime at electrical field strengths of 1 and $2 \mathrm{kV} / \mathrm{mm}$, and a frequency of $1 \mathrm{rad} / \mathrm{s}$. After an initial period with the electrical field on and off, at an electrical field strength of $1 \mathrm{kV} / \mathrm{mm}$, the storage modulus $\mathrm{G}^{\prime}(\omega=1 \mathrm{rad} / \mathrm{s})$ of 
XL/Al_0, increases and subsequently reaches a steady-state value. While the storage modulus of $\mathrm{XL} / \mathrm{Al}$ - 7 initially increases, and then decreases slowly as the electrical field is turned off; it does not recover its original value. This behavior indicates that there are some irreversible interactions, perhaps due to the ionic bonding between small alumina particles within the matrix.

Figure 5. Temporal response of the storage modulus $\left(\mathrm{G}^{\prime}\right)$ of $\mathrm{XL} / \mathrm{Al} \_0$ and XL/Al_7 at electrical field strengths of 1 and $2 \mathrm{kV} / \mathrm{mm}$, frequency $1.0 \mathrm{rad} / \mathrm{s}$, strain $0.1 \%$, and at $27^{\circ} \mathrm{C}$.

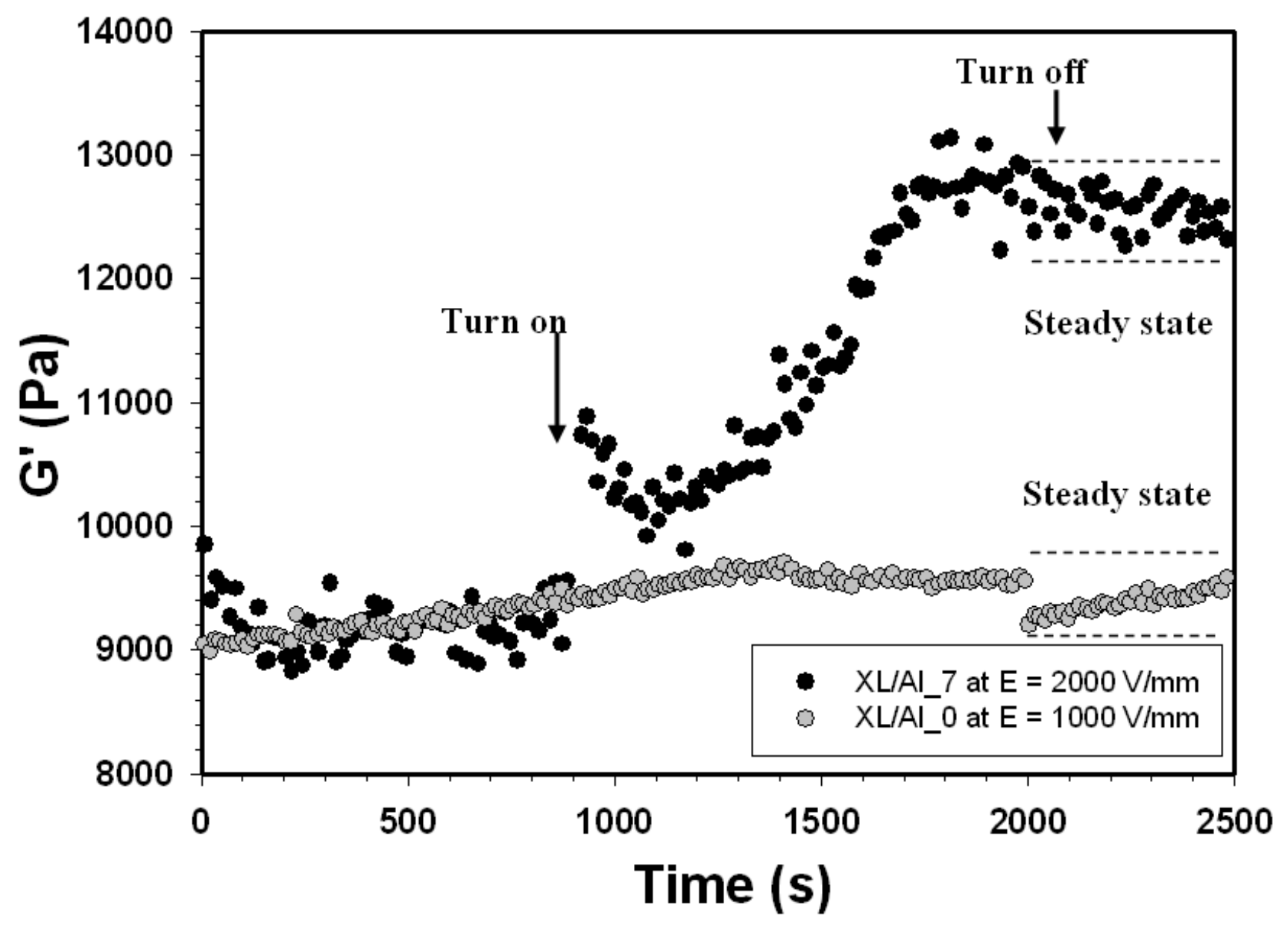

Figures $6\left(\right.$ a) and (b) show the storage modulus $\left(G^{\prime}\right)$ and the loss modulus $\left(G^{\prime \prime}\right)$ vs. frequency of the XL/Al_0 and XL/Al_7 composites at the electrical field strengths of 0,1 , and $2 \mathrm{kV} / \mathrm{mm}$. In the absence of an electrical field, $G^{\prime}$ is greater than $G^{\prime \prime}$ at all frequencies for both XL/Al_0 and XL/Al_7 systems, indicating that these samples possess the solid-like behavior. A composite system with a volume fraction of 0.00968 (XL/Al_7) exhibits the highest electrorheological responses, the storage modulus $\mathrm{G}^{\prime}(\omega)$ and the loss modulus $\mathrm{G}^{\prime \prime}(\omega)$, under the stimulation of an external electrical field. For the XL/Al_0 system, the $\mathrm{G}^{\prime}(\omega=1 \mathrm{rad} / \mathrm{s})$ increases from $\sim 1.16 \times 10^{4} \mathrm{~Pa}$ to $1.25 \times 10^{4} \mathrm{~Pa}$ as the electrical field is varied from 0 to $2 \mathrm{kV} / \mathrm{mm} ; \Delta \mathrm{G}^{\prime}=0.09 \times 10^{4} \mathrm{~Pa}$. For the XL/Al_7 system, the $\mathrm{G}^{\prime}(\omega=1 \mathrm{rad} / \mathrm{s})$ increases from $\sim 2.00 \times 10^{4} \mathrm{~Pa}$ to $2.44 \times 10^{4} \mathrm{~Pa}$ as the electrical field is varied from 0 to $2 \mathrm{kV} / \mathrm{mm}$; $\Delta \mathrm{G}^{\prime}=0.44 \times 10^{4} \mathrm{~Pa}$. The storage modulus of the composite without alumina (XL/Al_0) increases significantly upon electrical fields from 0 to $2 \mathrm{kV} / \mathrm{mm}$ because natural rubber (XL) is an elastic elastomer. The XL elastic behavior is caused by bond distortions. In its relaxed state rubber consists of 
long, coiled-up polymer chains that are interlinked and rotate freely about its neighbor. As an electrical field is applied, bond lengths deviate from the minimum energy equilibrium and the strain energy is stored electrostatically.

Figure 6. Moduli of $\mathrm{XL} / \mathrm{Al} \_0$ and $\mathrm{XL} / \mathrm{Al} \_7$ vs. frequency at various electrical field strengths: 0,1 , and $2 \mathrm{kV} / \mathrm{mm}$; and at $27^{\circ} \mathrm{C}$ : a) Storage modulus, $\mathrm{G}^{\prime}(\omega)$; b) Loss modulus, $\mathrm{G}^{\prime \prime}(\omega)$.
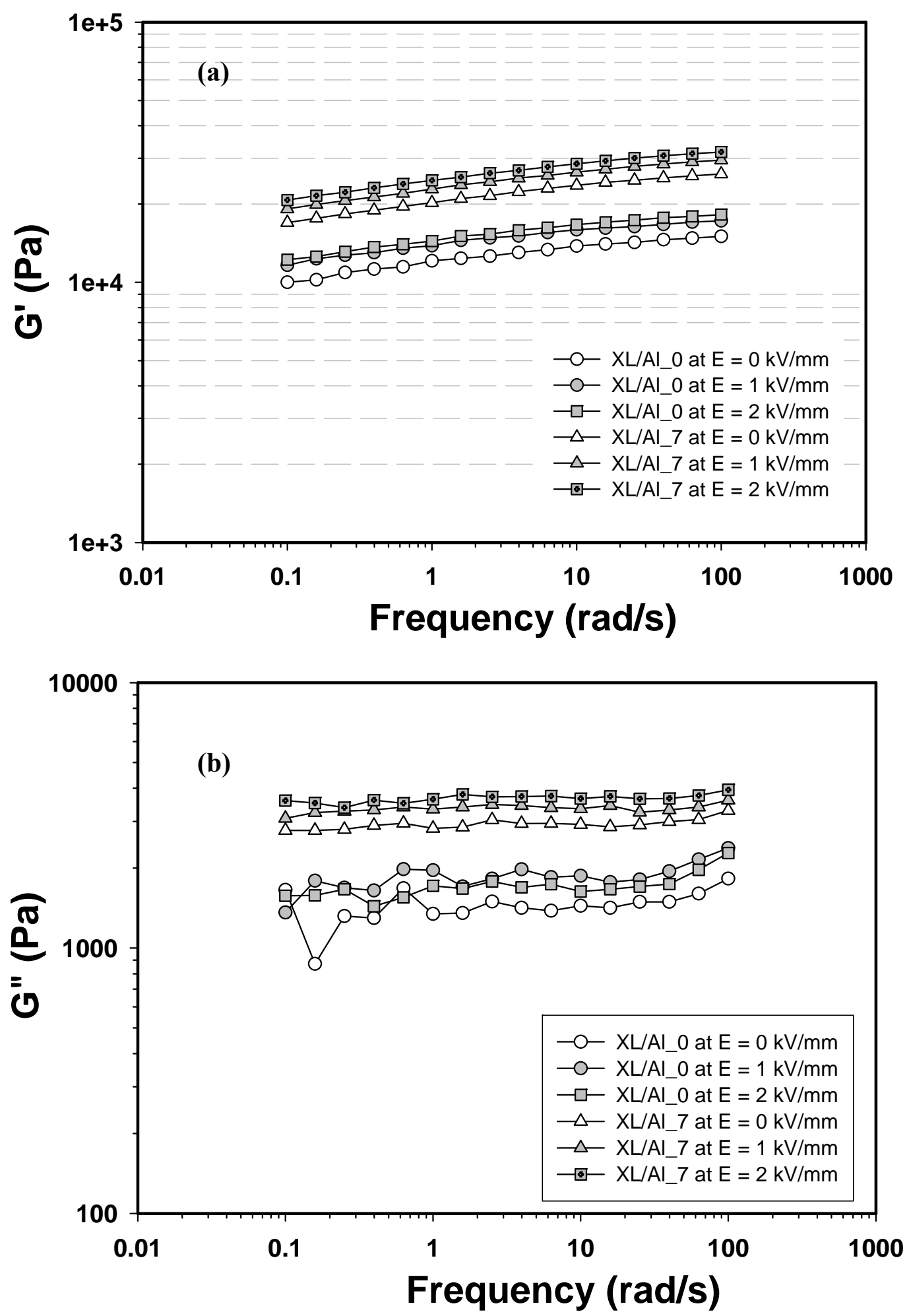
Figure 7. (a) Storage modulus response, $\Delta \mathrm{G}^{\prime}(\omega=1 \mathrm{rad} / \mathrm{s}, 2 \mathrm{kV} / \mathrm{mm})$ and $\mathrm{G}^{\prime}{ }_{\mathrm{o}}(\omega=1 \mathrm{rad} / \mathrm{s})$, of the XL/Al_7 composites as functions of particle volume fraction at $27{ }^{\circ} \mathrm{C}$. (b) $\Delta \mathrm{G}^{\prime}(\omega) / \mathrm{G}^{\prime}{ }_{0}(\omega)$ of the $\mathrm{XL} / \mathrm{Al}_{2} \mathrm{O}_{3}$ composite as a function of particle volume fraction at an electrical field strength of $2 \mathrm{kV} / \mathrm{mm}$, and at a temperature of $27^{\circ} \mathrm{C}$.
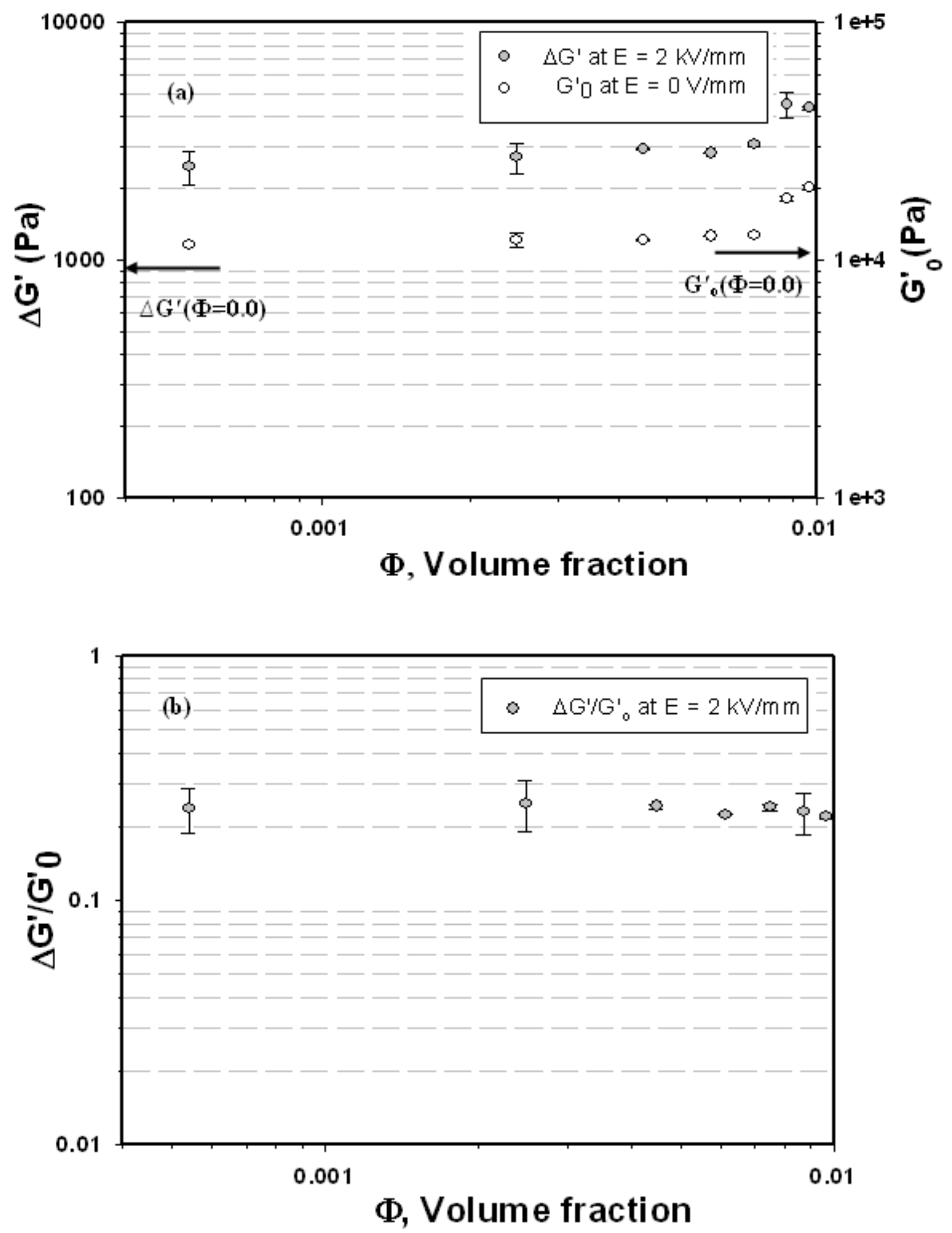
Figure 7 (a) shows the storage modulus response, $\Delta \mathrm{G}^{\prime}(\omega=1 \mathrm{rad} / \mathrm{s})$, vs. particle volume fraction at the electrical field strengths of $2 \mathrm{kV} / \mathrm{mm}$. In this figure, we also show the storage modulus, $\mathrm{G}^{\prime}{ }_{\mathrm{o}}(\omega=1 \mathrm{rad} / \mathrm{s})$, without an electrical field versus particle volume fraction. Both $\Delta \mathrm{G}^{\prime}$ and $\mathrm{G}_{\mathrm{o}}^{\prime}$ appear to increase monotonically with increasing particle volume fraction. For the storage modulus $\mathrm{G}^{\prime}{ }_{\mathrm{o}}(\omega=1 \mathrm{rad} / \mathrm{s})$ without an electrical field, the storage modulus increases from 11,590 Pa to 20,011 Pa as the volume fraction is varied from 0.00000 to 0.00968 , as also tabulated in Table 3. Figure 7(b) shows the storage modulus sensitivity, $\Delta \mathrm{G}^{\prime} / \mathrm{G}^{\prime}{ }_{\mathrm{o}}$, vs. particle volume fraction. The storage modulus sensitivity values at an electrical field strength of $2 \mathrm{kV} / \mathrm{mm}$ are $7.8854 \%$ (XL/Al_0), 23.6483\% (XL/Al_1), 24.6102\% (XL/Al_2), 24.1534\% (XL/Al_3), 22.3179\% (XL/Al_4), 23.9230\% (XL/Al_5), $22.8915 \%$ (XL/Al_6), and $21.8755 \%$ (XL/Al_7). The storage modulus sensitivity of our composites is thus nearly independent of particle volume fractions; but it is higher than that of pure natural rubber (XL/Al_0).

The storage moduli $\mathrm{G}^{\prime}(\omega=1 \mathrm{rad} / \mathrm{s})$ vs. electrical field of the three composites (XL/Al_0, XL/Al_4, and XL/Al_7) at various electrical field strengths are shown in Figure $8 . \mathrm{G}^{\prime}(\omega=1 \mathrm{rad} / \mathrm{s})$ increases monotonically with electrical field within the range of $0.005-2 \mathrm{kV} / \mathrm{mm}$. The storage modulus values, $\mathrm{G}^{\prime}(\omega=1 \mathrm{rad} / \mathrm{s})$, of these systems at an electrical field strength of $2 \mathrm{kV} / \mathrm{mm}$ are 14411,16184 , and 24656 Pa for XL/Al_0, XL/Al_4, and XL/Al_7, respectively. In the absence of an electrical field, the alumina particles are randomly dispersed within the natural rubber XL matrix and there is no particle interaction. As an electrical field is applied, both alumina particles and XL particles become ionically polarized and induced dipole moments are generated, leading to intermolecular interactions. These intermolecular interactions induce the loss of chain free movements and higher chain rigidity, as indicated by higher $\mathrm{G}^{\prime}(\omega)$ values. The electrical field evidently enhances the elastic modulus of our dielectrical ceramic-polymer composite materials by nearly a factor of two.

Figure 8. Storage modulus, $\mathrm{G}^{\prime}(\omega=1 \mathrm{rad} / \mathrm{s})$, of XL/Al_0, XL/Al_4, and XL/Al_7 vs. electrical field strength, at a frequency of $1 \mathrm{rad} / \mathrm{s}$, and at $27^{\circ} \mathrm{C}$.

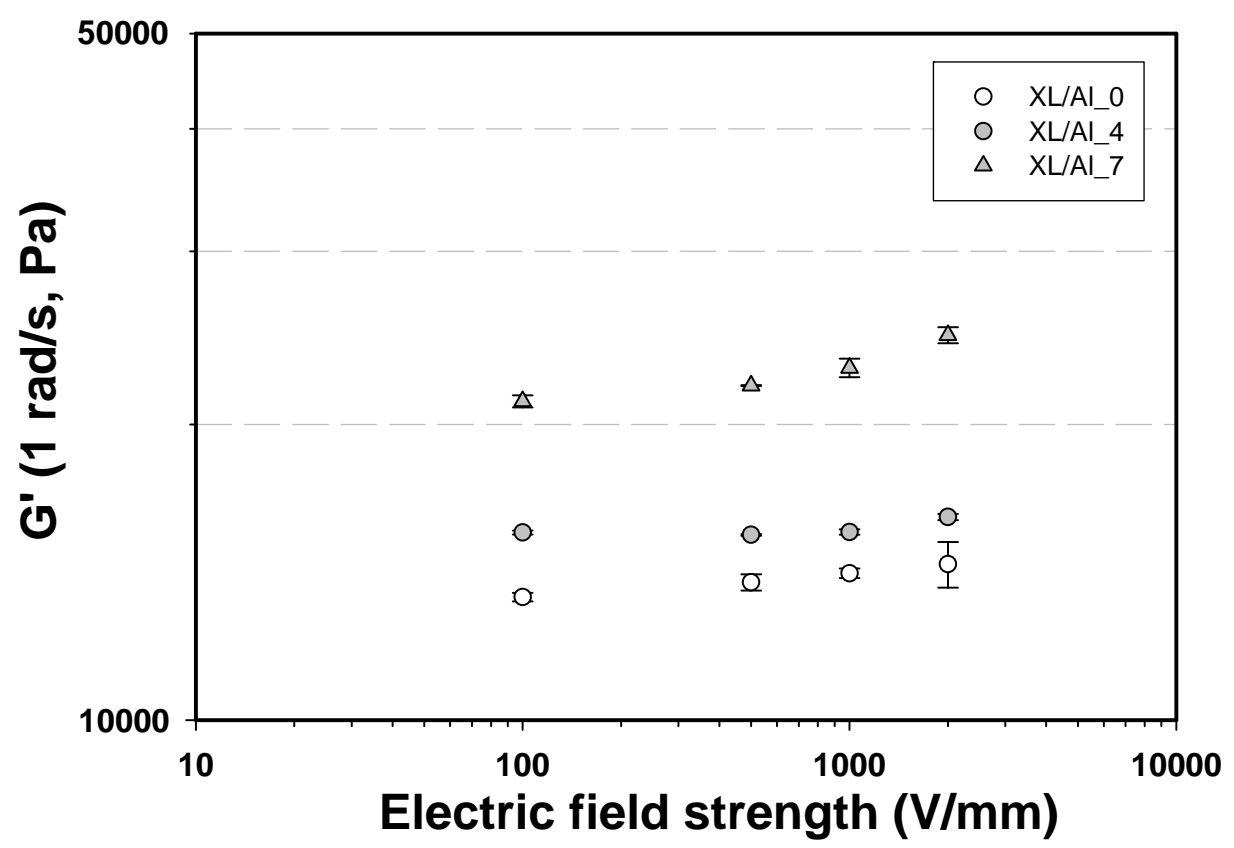


Table 3. Rheological properties of composite materials of natural rubber (XL) and alumina $\left(\mathrm{Al}_{2} \mathrm{O}_{3}\right)$ measured at $1 \mathrm{rad} / \mathrm{s}$ and at $27{ }^{\circ} \mathrm{C}$.

\begin{tabular}{|c|c|c|c|c|c|c|c|}
\hline Code & $\begin{array}{l}\mathrm{V} / \mathrm{V} \text { of } \\
\mathrm{Al}_{2} \mathrm{O}_{3} \\
\end{array}$ & $\begin{array}{l}\mathbf{G}_{0}^{\prime} \\
(\mathbf{P a}) \\
\end{array}$ & $\begin{array}{c}\mathbf{G}_{2 \mathrm{kV} / \mathrm{mm}}^{\prime} \\
(\mathbf{P a})\end{array}$ & $\begin{array}{l}\mathrm{G}^{\prime \prime}{ }_{0} \\
(\mathrm{~Pa}) \\
\end{array}$ & $\begin{array}{c}\mathrm{G}^{\prime \prime} 2 \mathrm{kV} / \mathrm{mm} \\
(\mathrm{Pa})\end{array}$ & $\begin{array}{c}\Delta \mathrm{G}^{\prime}{ }_{2 \mathrm{kV} / \mathrm{mm}} \\
(\mathrm{Pa})\end{array}$ & $\begin{array}{c}\Delta \mathbf{G}_{2}^{\prime} \\
\mathrm{kV} / \mathrm{mm}^{\prime} / \mathbf{G}_{0}^{\prime}\end{array}$ \\
\hline XL/Al_0 & 0.00000 & 11,589 & 12,503 & 1,344 & 1,476 & 913 & 0.0788 \\
\hline XL/Al_1 & 0.00054 & 11,677 & 14,439 & 1,458 & 1,565 & 2,761 & 0.2364 \\
\hline XL/Al_2 & 0.00248 & 12,704 & 15,831 & 1,537 & 1,609 & 3,126 & 0.2461 \\
\hline XL/Al_3 & 0.00448 & 12,269 & 15,233 & 1,559 & 1,689 & 2,963 & 0.2415 \\
\hline XL/Al_4 & 0.00613 & 12,634 & 15,454 & 1,609 & 2,263 & 2,819 & 0.2231 \\
\hline XL/Al_5 & 0.00750 & 12,736 & 15,783 & 2,076 & 2,339 & 3,046 & 0.239 \\
\hline XL/Al_6 & 0.00873 & 17,941 & 22,048 & 2,080 & 2,640 & 4,107 & 0.2289 \\
\hline XL/Al_7 & 0.00968 & 20,010 & 24,387 & 2,826 & 3,638 & 4,377 & 0.2187 \\
\hline
\end{tabular}

All properties were measured at the frequency $1 \mathrm{rad} / \mathrm{s}$, the strain of $0.1 \%$, and the temperature of $27{ }^{\circ} \mathrm{C} . \mathrm{G}^{\prime}{ }_{\mathrm{o}}$ and $\mathrm{G}^{\prime \prime}{ }_{\mathrm{o}}$ are the storage and the loss moduli without an electrical field; $\mathrm{G}_{2 \mathrm{kV} / \mathrm{mm}}$ and $\mathrm{G}^{\prime \prime}{ }_{2 \mathrm{kV} / \mathrm{mm}}$ are the storage and the loss moduli at $2 \mathrm{kV} / \mathrm{mm} ; \Delta \mathrm{G}_{2 \mathrm{kV} / \mathrm{mm}}$ is the storage modulus response defined as $\mathrm{G}_{2 \mathrm{kV} / \mathrm{mm}}^{\prime}-\mathrm{G}_{\mathrm{o}}^{\prime} ; \Delta \mathrm{G}_{2 \mathrm{kV} / \mathrm{mm}}^{\prime} / \mathrm{G}_{\mathrm{o}}^{\prime}$ is the storage modulus sensitivity.

\section{Experimental Section}

\subsection{Materials}

Aluminum oxide $\left(\mathrm{Al}_{2} \mathrm{O}_{3}\right)$ was purchased from Sigma-Aldrich Chemical Co., Ltd. (USA). The specific gravity of the alumina powder was $3.90 \mathrm{~g} / \mathrm{cm}^{3}$. Hexane (HPLC grade) was obtained from LabScan Co., Ltd. The starting natural rubber (STR XL or Standard Thai Rubber XL, STR XL, XL) was supplied by Venus Technology Co., Ltd. (VTEC, Thailand). STR XL is a dried rubber type in an extra light color slab and with a low dirt content of less than $0.04 \%$. The specific gravity, impurity content, Mooney viscosity, initial plasticity, and plasticity retention of natural rubber (STR XL) are $0.92 \mathrm{~g} / \mathrm{cm}^{3}$, $0.02 \%$ by weight, $62.8,32.0$, and 81.3 , respectively. This natural rubber (STR XL) exhibits a high compounded gum tensile strength, good hot tensile properties, and possesses low level non-polymer constituents $[5,11,26]$. The chemical structure is shown in Scheme 1.

Scheme 1. Polyisoprene structure.

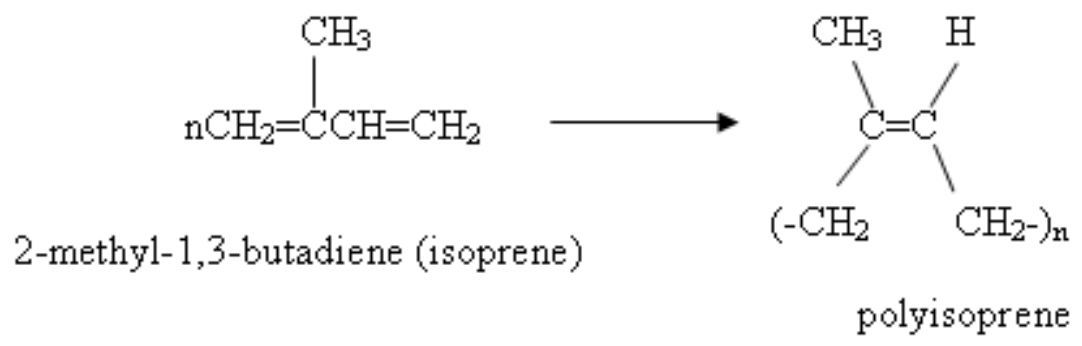




\subsection{Instruments}

Fourier transform infrared spectra (FTIR) were recorded on a Perkin Elmer, model Spectrum One spectrometer with a spectral resolution of $4 \mathrm{~cm}^{-1}$. The samples were mixed with the single-crystal potassium bromide $(\mathrm{KBr})$.. X-ray diffraction (XRD) data were taken and analyzed using a Bruker, D8 Discover analyzer with a VANTEC-1 detector and a double-crystal wide-angle goniometer. Scans were obtained from $10^{\circ}$ to $80^{\circ} 2 \theta$ at a scan speed of $5^{\circ} 2 \theta / \mathrm{min}$ in $0.05^{\circ}$ or $0.03^{\circ} 2 \theta$ increments using $\mathrm{CuK} \alpha$ radiation $(\lambda=0.154 \mathrm{~nm})$. Peak positions were compared with standard JCPDS files to identify the crystalline phases. SEM micrographs were obtained using a scanning electron microscope (SEM, JEOL-5200) equipped with EDS for X-ray microanalysis. The samples of natural rubber XL, $\mathrm{XL} / \mathrm{Al}_{2} \mathrm{O}_{3}$, and alumina powder $\left(\mathrm{Al}_{2} \mathrm{O}_{3}\right)$ were mounted on a stub using carbon paste and were sputtercoated to $\sim 0.1 \mu \mathrm{m}$ of gold to improve conductivity. An acceleration voltage of $20 \mathrm{kV}$ with magnifications of 1000 and 3200 times were used. The electrical properties were measured and obtained using an impedance analyzer (HP, model 16451B) equipped with an LCR meter (HP, model 4284A). The samples were prepared according to the ASTM B263-94 standard for the electrical property measurement. Composite samples were prepared as thin discs having a diameter of $38 \mathrm{~mm}$ and a thickness of $0.50 \mathrm{~mm}$. In our experiment, the electrical properties were measured at frequencies from 500 to $10^{6} \mathrm{~Hz}$ with an $\mathrm{AC}$ current of $2 \mathrm{~A}$ for samples at various volume fractions: $\Phi=\frac{\nu_{\text {disperse }}}{v_{\text {total }}}$, where $\Phi$ is the volume fraction of the dispersed phase or alumina $\left(\mathrm{Al}_{2} \mathrm{O}_{3}\right), V_{\text {diperse }}$ is the volume of the dispersed phase $\left(\mathrm{Al}_{2} \mathrm{O}_{3}\right)$, and $V_{\text {total }}$ is the total volume of the dispersed phase $\left(\mathrm{Al}_{2} \mathrm{O}_{3}\right)$ and the matrix (STR XL) phase.

The measured electrical resistivity of the composite materials was converted to electrical conductivity as follows [27]:

$$
\rho_{\text {eff }}=\frac{R A}{L}=\frac{1}{\sigma}
$$

where $\rho_{\text {eff }}$ is the effective resistivity $(\Omega . \mathrm{m}), R$ is the resistance $(\Omega), A$ is the cross-section discs $\left(\mathrm{m}^{2}\right)$, and $L$ is the thickness (m).

A controlled-strain rheometer (Rheometric Scientific Inc., ARES) was used to measure the dynamic rheological properties of the composites under controlled strain with a copper parallel plate geometry (25 $\mathrm{mm}$ in diameter). The typical sample thickness of the parallel plate gap was $1.0 \pm 0.1 \mathrm{~mm}$. An electrical field for the ER measurement was applied using a high voltage power supply (Keithley, model 2410). Strain sweep tests were first carried out to determine the suitable strains to measure as functions of frequency at various DC electrical field strengths. The samples were pre-sheared at a low frequency $(0.04 \mathrm{rad} / \mathrm{s})$ with the electrical field on for $9 \mathrm{~min}$ in order to attain the equilibrium polarization. Each measurement was carried out at $27^{\circ} \mathrm{C}$ and was repeated at least two or three times. Cumulative and fractional distributions were measured by using a particle size analyzer (Mastersizer $\mathrm{S}$, model Polydisperse 2.19). The samples were dispersed in a water medium and vibrated in an ultrasonic cleaner for $20 \mathrm{~min}$.

Bulk densities of the alumina particles, the elastomer, and the composites were determined using a pynconometer by weighing the samples of known volumes with an accurate 4-digit balance. The 
composite densities were calculated from $\rho_{C}=\rho_{p} \Phi+\rho_{m}(1-\Phi)$, where $\rho_{\mathrm{c}}, \rho_{p}$ and $\rho_{m}$ are the densities $\left(\mathrm{g} / \mathrm{cm}^{3}\right)$ of the composites, the alumina, and the elastomer, respectively. Chemical compositions were obtained using an Oxford, model ED2000 X-ray fluorescence spectrometer (XRF), with a tube current of $1000 \mu \mathrm{A}$ and an acquisition lifetime of $30 \mathrm{~s}$.

\subsection{Sample Preparation of ER Solid}

ER suspensions, with alumina particulate volume fractions of 0.00000 (XL/Al_0), 0.00054 (XL/Al_1), 0.00248 (XL/Al_2), 0.00448 (XL/Al_3), 0.00613 (XL/Al_4), 0.00750 (XL/Al_5), 0.00873 (XL/Al_6), 0.00968 (XL/Al_7), were prepared. The non-polar molecules tend to be soluble in non-polar solvents such as hexane, carbon tetrachloride, diethyl ether, and benzene. The dried natural rubber (XL) samples were swollen in a $20 \%$ by volume hexane solution. The hexane was HPLC grade with a density of $0.655 \mathrm{~g} / \mathrm{cm}^{3}$, a relative permittivity of 2.0 , and it is colorless. The alumina particles were dispersed using a magnetic bar stirrer at room temperature for $24 \mathrm{~h}$. Each suspension was then poured into a Petri dish glass and allowed to dry at room temperature overnight. A thin disc with the thickness less than $0.5 \mathrm{~mm}$ and of light yellow in color was obtained.

\section{Conclusions}

The experimental data show that the XL/Al_7 composite with an $\mathrm{Al}_{2} \mathrm{O}_{3}$ particle volume fraction of 0.00968 has the highest electrical and electrorheological responses. The electrical properties, namely dielectric constant and electrical conductivity, of XL/Al_7 are 2.123 and $2.683 \times 10^{-8}(\Omega . \mathrm{m})-1$, respectively. With and without an electrical field, the dynamic moduli $\mathrm{G}^{\prime} \mathrm{o}, \mathrm{G}^{\prime} 2 \mathrm{kV} / \mathrm{mm}, \mathrm{G}^{\prime \prime} \mathrm{o}$, $\mathrm{G}^{\prime \prime} 2 \mathrm{kV} / \mathrm{mm}$, and $\Delta \mathrm{G}^{\prime} / \mathrm{G}^{\prime} \mathrm{o}$ of the XL/Al_7 composite are $20011 \mathrm{~Pa}, 24388 \mathrm{~Pa}, 2827 \mathrm{~Pa}, 3639 \mathrm{~Pa}$, and $21.88 \%$, respectively. Our results suggest that small amounts of alumina $\left(\mathrm{Al}_{2} \mathrm{O}_{3}\right)$ particles can be used as a filler to absorb loss and store additional elastic energy within the natural rubber matrix under electrical field. The XL/A12O3 composites studied are soft and flexible materials and potential candidates for biomimetric actuators and/or artificial muscles.

\section{Acknowledgements}

The authors would like to thank the following: the Conductive and Electroactive Polymers Research Unit of Chulalongkorn University; the Thailand Research Fund (BRG grant); the Royal Thai Government (Budget of Fiscal Year 2008); the Petroleum, Petrochemical and Advanced Materials Consortium; the Faculty of Engineering, Kasetsart University; and, the Departments of Materials Engineering and Physics, at Kasetsart University for the use of analytical equipment. We also thank the grant support from the Small Projects on Rubber (SPR) of the Thailand Research Fund.

\section{References and Notes}

1. Dias, C.J.; Das-Gupta, D.K. Inorganic ceramic/polymer ferroelectric composite electrets. IEEE Trans. Dielectr. Electr. Insul. 1996, 3, 706-734.

2. Tian, Y.; Meng, Y.; Wen, S. Particulate volume effect in suspensions with strong electrorheological response. Mat. Lett. 2003, 57, 2807-2811. 
3. Carpi, F.; Rossi, D.D. Dielectric elastomer cylindrical actuators: electromechanical modeling and experimental evaluation. Mat. Sci. Eng. C 2004, 24, 555-562.

4. López-Manchado, M.A.; Valentin, J.L.; Carretero, J.; Barroso, F.; Arroyo, M. Rubber network in elastomer nanocomposites. Eur. Polym. J. 2007, 43, 4143-4150.

5. Najidha, S.; Saxena, N.S.; Sreeja, R.; Unnithan, C.H.; Predeep, P. Optical and electrical characterization of $\mathrm{SbCl}_{5}$ doped cis-1,4-polyisoprene. Mat. Lett. 2005, 59, 3431-3436.

6. Lowery, T.H; Richardson, K.S. Solvent, Mechanism and Theory in Organic Chemistry; Harper Collins: New York, NY, USA, 1998; p. 181.

7. Sutorik, A.C.; Neo, S.S.; Treadwell, D.R.; Laine, R.M. Synthesis of ultrafine $\beta$ "-alumina powders via flame spray pyrolysis of polymeric precursors. J. Am. Ceram. Soc. 1998, 81, 1477-1486.

8. Kummer, J.T; Weber, N. Energy conversion device comprising a solid crystalline electrolyte and a solid reaction zone separator. US Pat. 3535163, 1970.

9. Yamagushi, G.; Suzuki, K. On the structures of alkalipolyaluminates. Bull. Chem. Soc. Jpn. 1968, 41, 93-99.

10. Vinod, V.S.; Varghese, S.; Kuriakose, B. Degradation behavior of natural rubber-aluminum powder composites: Effect of heat, ozone and high energy radiation. Polym. Degrad. Stab. 2002, $75,405-412$.

11. Jakubowickz, I. Evaluation of degradability of biodegradable polyethylene (PE). Polym. Degrad. Stab. 2003, 39-43.

12. Parthasarathy, M.; Klingenberg, D.J. Electrorheology: Mechanisms and models. Mat. Sci. Eng., 1996, 17, 57-103.

13. Rob, D.F.M. Taalman Isoprene: Background and issues. Toxicology 1996, 113, 242-246.

14. Dorre, E; Hubner, H. Alumina; Springer-Verlag: New York, NY, USA, 1984; p. 329.

15. Mirfakhrai, T.; Madden, J.D.W.; Baughman, R.H. Polymer artificial muscles. Mater. Today 2007, $10,30-38$.

16. Moschou, E.A.; Madou, M.J.; Bachas L.G.; Daunert, S. Voltage-switchable artificial muscles actuating at near neutral pH. Sens. Actuat. B 2006, 115, 379-383.

17. Shiga, T. Deformation and viscoelastic behavior of polymer gels in electric fields. Adv. Polym. Sci. 1997, 134, 131-163.

18. Wu, C.W.; Conrad, H. Electrical properties of electrorheological particle clusters. Mater. Sci. Eng. A 1998, 255, 66-69.

19. Mitsumata, T.; Sugitani. K.; Koyama. K. Electrorheological response of swollen silicone gels containing barium titanate. Polymer 2004, 45, 3811-3817.

20. Kim, Y.D.; Klingenberg, D.J. Two roles of nonionic surfactants on the electrorheological response. J. Colloid Interface Sci. 1996, 183, 568-578.

21. Kim, Y.D; Song, I.C. Electrorheological and dielectric properties of polypyrrole dispersions. $J$. Mat. Sci. 2002, 37, 5051-5055.

22. Sohn, J.I.; Sung, J.H.; Choi, H.J.; Jhon, M.S. The effect of particle concentration of poly(p-phenylene) on electrorheological response. J. Appl. Polym. Sci. 2002, 84, 2397-2403.

23. Zhang, L.; Luo, Y.; Hou, Z. Unprecedented Isospecific 3, 4-Polymerization of isoprene by cationic rare earth metal alkyl species resulting from a binuclear precursor. J. Am. Chem. Soc. 2005, 127, 14562-14563. 
24. Ismail, Y.A.; Shin, S.R.; Shin, K.M.; Yoon, S.G.; Shon, K.; Kim, S.I. Electrochemical actuation in chitosan/polyaniline microfibers for artificial muscles fabricated using an in situ polymerization. Sens. Actuat. B 2008, 129, 834-840.

25. Chappell, P.H.; Cranny, A.; Cotton, D.P.J.; White, N.M.; Beeby, S.P. Sensory motor systems of artificial and natural hands. Inter. J. Surg. 2007, 5, 436-440.

26. Tardif, O.; Nishiura, M.; Hou, Z. Rare earth alkyl and hydride complexes bearing silylene-linked cyclopentadienyl-phosphido ligands. Synthesis, structures, and catalysis in olefin hydrosilylation and ethylene polymerization. Tetrahedron 2003, 59, 10525-10539.

27. Callister, W.D. Materials Science and Engineering an Introduction, 7th ed.; John Wiley \& Sons, Inc.: Hoboken, NJ, USA, 2007; p. 806.

28. Kansal, P.; Laine, R.M. A processable mullite precursor prepared by reacting silica and aluminum hydroxide with triethanolamine in ethylene glycol: Structural evolution on pyrolysis. J. Am. Ceram. Soc. 1997, 80, 2597-2606.

(C) 2010 by the authors; licensee Molecular Diversity Preservation International, Basel, Switzerland. This article is an open-access article distributed under the terms and conditions of the Creative Commons Attribution license (http://creativecommons.org/licenses/by/3.0/). 